\title{
Mandailing Phonological Variation in Mandailing Natal Regency
}

\author{
Sholihatul Hamidah Daulay, Robert Sibarani, Nadra, Matius C.A Sembiring \\ Postgraduate School of Linguistic Department, North Sumatera University, Indonesia
}

\begin{abstract}
This article attempted to discuss about Mandailing phonological variation in Mandailing Natal Regency. As observation points, this study was determined 21 villages from all districts in Mandailing Natal and the data were analyzed by using dialectometri application. The objectives of the study were to describe the phonological variation of Mandailing language, the distribution maps and line isogloss on phonological elements of Mandailing language and the grouping of dialect on phonology based dialectometri method. To calculate the dialectometri vocabulary has been done by calculating all of the vocabulary per field of meaning which amounts to 800 glosses. However, the phonological dialectometri not be counted per field of meaning because of the differences can be found in several fields of meaning. Thus, the calculation should be done phonological dialectometri overall meaning of the phonological changes, the difference in phonological distance at Mandailing language totaled 105 glosses.
\end{abstract}

Keywords: phonological variation, isogloss line, dialectometri

\subsection{Background}

\section{Introduction}

Indonesian consisting of various ethnic and cultural diversity of backgrounds have different sosiocultur anyway. One of the cultural diversity of the language in question is, in this case the local languages. The regional languages have different systems with each other. Local language is one source of Indonesian vocabulary that needs to be fostered. Development and maintenance of the local language is not meant to shift the position of Indonesian as the national language and the language of the country, but to facilitate communication links between communities in a particular area.

Mandailing is a region of Mandailing Natal in the middle of North Sumatra province, and territory located along the cross-Sumatra highway approximately $40 \mathrm{~km}$ from Padangsidempuan to the south, and approximately 150 miles from Bukittinggi to the north. Mandailing Angkola borders to the north, the coast on the west, Minangkabau in the south, as well as Padanglawas in the east.

Based on the above conditions, it is necessary and important to do research on dialect variation in the field of Mandailing phonology. In addition, research is very interesting dialectology applied to the Mandailing language contained in Mandailing Natal because of this research will be stressed to see dialect variations that arise on the Mandailing language at some observation points in the district. As for some of the variations of the sound to the word that symbolizes the same meaning, there is the meaning of 'pretty' is pronounced $[\mathrm{d} \square \mathrm{g} \square \mathrm{s}]$ and $[\mathrm{j} \square \mathrm{g} \square \mathrm{s}]$;the meaning of 'no' uttered by [inda $\square]$ and [inda]; the word 'dry' is pronounced [h $\square \mathrm{rij}$ ] and $[\mathrm{k} \square \mathrm{rin}]$; the word 'high' is pronounced [ginjay] and [injay]; and the word 'interest' is pronounced [buna] and $[$ buy $\square]$.

\subsection{Purpose of Study}

This study focuses on the study of dialect variation caused by different speakers are located geographically. The purpose of study is to describe the phonological variation of Mandailing language, to map the distribution of the elements and isogloss lines phonological Mandailing language and to group dialect on phonological based dialectometri method.

\section{Theoretical Review}

The approach used in this study is Ayatrohaedi's (1985: 30) stated that the term dialect is derived from the Greek word dialektos. At first this dialektos declared the Greek language has only a slight difference. Therefore, the main characteristic dialect is the difference in unity, and unity in diversity. Nothofer (1993: 169) reveal a dialect geography research necessary for the observation point. Among the point of observation or from one observation point to observation point adjacent diagonal lines required. Diagonal line drawn must not intersect each other. Thus, the diagonal line connecting the point of observation to the observation point closer can be used as a benchmark in determining the differences that lead to the dialect of a language, subdialect a language, or a language difference is still a difference of speech. 
To facilitate reading the data map (giving of) used a line that will enclose the area of providing such use. The line was called isoglosses, the imaginary line connecting each point of observation that displays symptoms similar language (Keraf, 1984: 54-164). The theory used in this study is the theory put forward by the experts comparative linguistics and dialectology, especially the theory proposed by Pop and Jaberg (Ayatrohaedi, 1978), Wardaugh (2009) which states that language variation is a variation in speech communication caused by geographical differences. However, when experienced by speakers of a language can be referred to as a dialect geography, which will describe each element to show the differences in the language itself, and can describe the differences in the map.

Dialectometri formula is as follows:

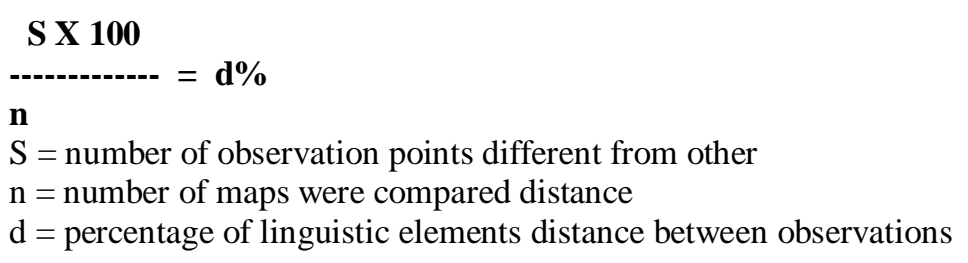

The difference in the field of phonology;

$17 \%$ to the top : perceived differences in language

$12-16 \%$ : $\quad$ perceived differences in dialect

$8-11 \%: \quad$ : $\quad$ perceived differences subdialect

$4-7 \%$ : $\quad$ perceived differences in speech

0-3\% : $\quad$ perceived no difference (Guiter, 1973: 96)

\section{Research Methodology}

The location of study is the population that using Mandailing language in Mandailing Natal Regency. Mandailing Natal Regency also often referred to Madina, the capital of Panyabungan. The twenty-three districts are Batahan, Batang Natal, Bukit Malintang, Huta Bargot, Kotanopan, Lembah Sorik Merapi, Lingga Bayu, Muara Batang Gadis, Muara Sipongi, Naga Juang, Natal, Pakantan, West Panyabungan, Panyabungan City, South Panyabungan, East Panyabungan, North Panyabungan, Puncak Sorik Merapi, Ranto Baek, Siabu, Sinunukan, Tambangan, and Ulu Pungkut. As observation points, this study was determined 21 villages from all districts in Mandailing Natal Regency. The following map illustrates the village maps that serve as observation points.

\section{Map 1. Regional Maps as Observation Point in Mandailing Natal Regency}

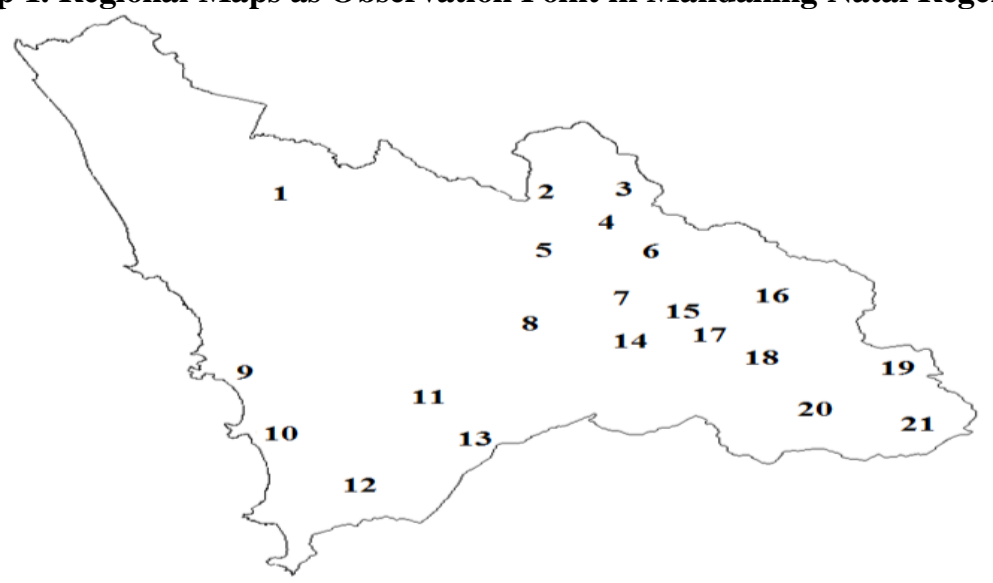

Specification:

$\begin{array}{ll}\text { 1. } & \text { Rantau Panjang village } \\ \text { 2. } & \text { Muara Batang Angkola village } \\ \text { 3. } & \text { Huta Bangun village } \\ \text { 4. } & \text { Sidojadi village } \\ \text { 5. } & \text { Huta Bargot Dolok village } \\ \text { 6. } & \text { Kota Siantar village } \\ \text { 7. } & \text { Kayu Laut village } \\ \text { 8. } & \text { Sopo Tinjak village } \\ \text { 9. } & \text { Pasar I Natal village } \\ \text { 10. } & \text { Pasar II Natal village } \\ \text { 11. } & \text { Simpang Bajole village }\end{array}$

2. Sinunukan IV village

13. Bangun Saroha village

14. Sibanggor Jae village

15. Pangkat village

16. Sirangkap village

17. Tambangan Tonga village

18. Sayur Maincat village

19. Tj. Alai village

20. Alahankae village

21. Huta Toras village 


\section{Discussion}

There are two methods that can be used in the discussion data, ie cakap methods and simak methods. According Sudaryanto (1993), the use of the term due to the way the provision of the data is done by listening. Here are vokoid couples who are in a similar minimal pair can be examplified as below.
1) /a/ dan /u/
$[1 \square$ ba $]$
'bee' (333)
2) /i/ dan / $\square /$
$[1 \square \mathrm{bu}]$
'pumpkin' (174)
[pinin]
'betel nut' (188)
[p $\square$ nin]
'dizziness' (397)
[angi]
'sister' (4)
[ang $\square]$
'if' (747)
[suri]
'comb' (376)
[sur $\square$ ]
3) /a/ dan / $\square /$
[ganjay]
'prayer rooms' (271)
[g $\square \mathrm{nj} \square \mathrm{y}]$
'tall' (645)
[lam-lam]
'bland' (630)
'necklace' (363)
$[1 \square \mathrm{m}-1 \square \mathrm{m}] \quad$ 'black' (697)

The phoneme or allophone status can be proved by using the principles of phonemes invention, ie to find minimal pairs or couples alike.
1) $\quad / \mathrm{h} / \mathrm{dan} / \mathrm{r} / \quad$ bahat] 'a lot' (651)
[barat] 'west' (570)
2) $/ \mathrm{g} / \mathrm{dan} / \mathrm{l} / \quad$ agas] 'insect' (344)
[alas] 'galangal' (175)
3) $\quad / \mathrm{d} / \mathrm{dan} / \mathrm{l} / \quad[\mathrm{g} \square \mathrm{day}]$ 'big' (647)

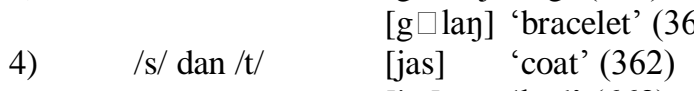
[jat] 'bad' (668)

\subsection{Vowel Phonemes Distribution}

The vocals on Mandailing language has seven phonemes distributed at the beginning, middle, and end. The examples of the distribution of vowel phonemes in the Mandailing language can be seen in the following table.

Table 1 Vowel Phonemes Distribution

\begin{tabular}{|c|c|c|c|}
\hline \multirow{2}{*}{ Phonem } & \multicolumn{3}{|l|}{ Distribution } \\
\hline & Beginning & Middle & End \\
\hline /i/ & [iyas] 'clean' (425) & $\begin{array}{l}\text { [hita] 'we' (46) } \\
\text { [siyamun] 'right' (565) }\end{array}$ & [boyi] 'forehead' (63) \\
\hline le/ & & [geda $\square$ ] 'big' (647) & \\
\hline$/ \mathrm{a} /$ & [abay] 'brother' (1) & $\begin{array}{l}\text { [gadun] 'cassava' (205) } \\
{[\text { g } \square \text { day] 'big' }(647)}\end{array}$ & $\begin{array}{l}\text { [sada] 'one' (206) } \\
\text { [rara] 'red' (699) }\end{array}$ \\
\hline$/ \mathrm{o} /$ & & & [kito] 'we' (46) \\
\hline$/ \mathrm{u} /$ & [ummah] 'kiss' (429) & $\begin{array}{l}\text { [buluy] 'leave' (158) } \\
\text { [tarutuy] 'durians' (159) }\end{array}$ & $\begin{array}{l}\text { [baru] 'new' (640) } \\
\text { [ulu] 'head' (62) }\end{array}$ \\
\hline I $\square /$ & [ $\square$ pat] 'four' (209) & {$[\mathrm{d} \square \mathrm{h} \square \mathrm{t}]$ 'with' (745) } & {$[\mathrm{da} \square]$ 'far' (657) } \\
\hline$/ \varepsilon /$ & {$[\varepsilon t \varepsilon \square]$ 'aunt' (21) } & $\begin{array}{l}\text { [ack] 'water' (597) } \\
\text { [pact] 'bit' (636) }\end{array}$ & [ate- at $\varepsilon]$ 'heart' (118) \\
\hline
\end{tabular}

\subsection{Consonant Phonemes Distribution}

The consonants of Mandailing language has nineteen phonemes distributed at the beginning, middle, and end. Examples of the distribution of consonant phonemes found in Mandailing language can be seen below.

Table 2 Consonant Phonemes Distribution

\begin{tabular}{|c|c|c|c|}
\hline \multirow[t]{2}{*}{ Phonem } & \multicolumn{3}{|l|}{ Distribution } \\
\hline & Beginning & Middle & End \\
\hline$/ \mathrm{p} /$ & [pacul] 'hoe' & [mapa $\square]$ 'stale' & [muap] 'smell' \\
\hline$/ \mathrm{b} /$ & [bar $\square]$ 'boils' & [labay] 'nail' & [tarub] 'roof' \\
\hline$/ \mathrm{m} /$ & [mag $\square]$ 'lost' & [aman] 'father' & [urum] 'cheek' \\
\hline$/ \mathrm{t} /$ & {$[\mathrm{t} \square$ bu] 'sugar cane' } & {$[\mathrm{g} \square \mathrm{ta}]$ 'sap' } & [ing $\square \mathrm{t}]$ 'remember' \\
\hline$/ \mathrm{d} /$ & [dana $\square]$ 'kid' & [ladin] 'machete' & \\
\hline
\end{tabular}


Mandailing Phonological Variation in Mandailing Natal Regency

\begin{tabular}{|l|l|l|l|}
\hline$/ \mathrm{n} /$ & {$[$ nayan] 'light' } & {$[\mathrm{landu} \square]$ 'deer' } & [ayan] 'basin' \\
\hline$/ \mathrm{c} /$ & {$[\mathrm{c} \square \mathrm{g} \square \mathrm{t}]$ 'tomorrow' } & {$[\mathrm{mac} \square \mathrm{m}]$ 'acid' } & \\
\hline$/ \mathrm{j} /$ & {$[$ jugu?] 'sit' [jat] 'bad' } & {$[$ ujin] 'aunt' } & \\
\hline$/ \tilde{\mathrm{n}} / \mathrm{l} / \mathrm{mañ} \square \mathrm{g} \square \mathrm{t}]$ 'morning' & {$[$ in $\square 1]$ 'deaf' } \\
\hline$/ \mathrm{k} /$ & {$[$ ñiyan] 'thin' } & {$[\mathrm{mal} \square]$ 'smart' } & \\
\hline
\end{tabular}

\subsection{Phonological dialectometri application}

The difference of the language sound, particularly in the Mandailing language, may occur regularly and irregularly (sporadic) closely related to the linguistic characteristics and geographic features. Therefore, the difference in regular and irregular variation related with two things, namely the linguistic characteristics and geographic features.

To calculate the dialectometri vocabulary has been done by calculating all of the vocabulary per field of meaning which amounts to 800 glosses. However, the phonological dialectometri not be counted per field of meaning because of the differences can be found in several fields of meaning. Thus, the calculation should be done phonological dialectometri overall meaning of the phonological changes. The difference in phonological distance at Mandailing language totaled 105 glosses. The phonological calculations are based on 800 glosses. There are 105 phonological map consists of several differences. Here is a table that will clarify the phonological differences.

Table 3 Phonological dialectometri application

\begin{tabular}{|c|c|c|}
\hline No. & Description and Example & Total \\
\hline 1 & {$[a-] \approx[\square-] / \# \_: a b u \approx \square$ bu 'ash' } & 9 \\
\hline 2 & {$[-\mathrm{a}] \approx[-\square] / \mathrm{K} \_\#:$ buya $\approx$ buy $\square$ 'flower' } & 7 \\
\hline 3 & {$[-\mathrm{a}-] \approx[-\square-] / \mathrm{K}_{-}: \mathrm{:} 1 \square \mathrm{ma} \square \approx$ lama $\square$ 'fat' } & 32 \\
\hline 4 & {$[\mathrm{sa}-] \approx[\square] /$ : salapan $\approx$ lapan 'eight' } & 1 \\
\hline 5 & {$[\mathrm{t}-] \approx[\mathrm{c}-] / \# \_$_ $:$tintin $\approx$ cincin 'ring' } & 1 \\
\hline 6 & {$[-\mathrm{n}-] \approx[-\mathrm{n}-] /: \mathrm{V}_{2} \quad:$ lan $\square \square \approx \operatorname{lan} \square$ 'fly' } & 2 \\
\hline 7 & {$[-\mathrm{a}-] \approx[-\mathrm{e}-] / \mathrm{K}_{-}:$kalsnten $\approx$ kelenten 'temple' } & 1 \\
\hline 8 & {$[-\mathrm{a}-] \approx[-\mathrm{e}-] \approx[-\square-] / \mathrm{K} \_:$mankudu $\approx$ meykudu $\approx \mathrm{m} \square$ ykudu 'morinda' } & 1 \\
\hline 9 & {$[-\mathrm{a}-] \approx[-\mathrm{u}-] / \mathrm{K}_{-} \quad$ : mas $\square$ jit/masaji $\square \approx$ mus $\square$ jit 'mosque' } & 2 \\
\hline 10 & {$[-\square-] \approx[-\varepsilon-] \approx[-\mathrm{a}-] / \mathrm{K} \_:$rabuw $\square \mathrm{y} \approx$ rebuy $\approx \mathrm{r} \square$ buy $\approx$ rebu $\square$ 'shoots' } & 3 \\
\hline 11 & {$[-\mathrm{i}-] \approx[-\mathrm{a}-] / \mathrm{K}_{-}$: pinin $\approx$ pinay 'betel nut' } & 4 \\
\hline 12 & {$[-\mathrm{u}-] \approx[-\square-] / \mathrm{K}_{-}$: kupiya $\approx \mathrm{k} \square$ piyah 'cap' } & 2 \\
\hline 13 & {$[-\mathrm{u}-] \approx[-\mathrm{i}-] / \mathrm{K}_{-} \quad:$ musay/musa $\square \approx$ misay 'civet' } & 1 \\
\hline 14 & {$[-\varepsilon-] \approx[-\mathrm{i}-] / \mathrm{K}_{-} \quad$ : past $\approx$ pait/pai $\square$ 'bitter' } & 2 \\
\hline 15 & {$[-\varepsilon-] \approx[-\mathrm{a}-]:$ sclatan $\approx$ salatan 'south' } & 2 \\
\hline 16 & {$[-\mathrm{R}] \approx[-\square] / \ldots \ldots$ \# : dapu $\square \approx$ dapuw $\square$ 'kitchen' } & 2 \\
\hline 17 & {$[-\mathrm{a}-] \approx[-\square-] / \mathrm{K}_{-} \quad$ : jari-jari $\approx \mathrm{j} \square$ ri-j $\square$ ri 'finger' } & 2 \\
\hline 18 & {$[-\mathrm{R}] \approx[-\mathrm{i}] /: \ldots \ldots \mathrm{iku} \square \approx$ ikui 'tail' } & 1 \\
\hline 19 & {$[\mathrm{~s}-] \approx[\square-] / \# \_\quad: \mathrm{s} \square \mathrm{ti} \square \approx \square \mathrm{ti} \square$ 'few' } & 1 \\
\hline 20 & {$[-\square] \approx[-\mathrm{y}] / \ldots \#$ : jambu a $\varepsilon \square \approx$ jambu aiy 'guava' } & 2 \\
\hline 21 & {$[\mathrm{c}-] \approx[\mathrm{s}-] / \# \_\mathrm{V}: \mathrm{c} \square \mathrm{yk} \square \square \approx \mathrm{s} \square \mathrm{yk} \square \square$ 'skull cap' } & 2 \\
\hline 22 & {$[\mathrm{~h}-] \approx[\square] / \# \quad \mathrm{~V}:$ hulit $\approx$ ulit 'skin' } & 4 \\
\hline 23 & {$[-\mathrm{n}] \approx[-\square] / \mathrm{V}_{-} \#:$ sumbin $\approx$ sumbi $\square$ 'cleft' } & 11 \\
\hline 24 & {$[-\mathrm{n}-] \approx[-\mathrm{s}-] /:$ pinta $\square \approx$ pista $\square \quad$ 'smart' } & 1 \\
\hline 25 & {$[\mathrm{~b}-] \approx[\mathrm{t}-] /$ buykusan $\approx$ tuykusan 'encasement' } & 1 \\
\hline 26 & 2 silabe $\sim 1$ silabe: ut $\square \square$ ut $\square \square \approx$ ut $\square \square$ 'brain' & 1 \\
\hline 27 & {$[-\square] \approx[-\mathrm{h}] / \ldots$ _\# : nana $\approx$ nanah 'pus' } & 4 \\
\hline 28 & {$[\mathrm{k}-] \approx[\square-] / \# \quad \ldots \quad \mathrm{V}:$ kuni $\square \approx$ uni $\square$ 'turmeric' } & 2 \\
\hline \multirow[t]{2}{*}{29} & {$[-1] \approx[\square] / \ldots$ \# : bantal $\approx$ banta 'pillow' } & 1 \\
\hline & Total & 105 \\
\hline
\end{tabular}

Furthermore, the calculation of the phonological dialectometri among obseration point by the following percentages.

a. Vocabulary distance showed no difference $(0 \%-3 \%)$ are the inter-observatoin points: 1:2, 1:3, 1: 5, $1: 8,2: 3,2: 5,3: 4,3: 5,3: 6,3: 16,4: 5,4: 6,5: 6,5: 7,5: 8,6: 7,6: 15,6: 16,7: 8,7: 14,7: 15,8: 11,8: 13,8: 14,9: 10$, $11: 12,11: 13,12: 13,12: 21,13: 14,13: 17,13: 18,13: 20,13: 21,14: 15,14: 16,14: 17,15: 16,16: 17,16: 18,17: 18$, 18:20, 20:21.

b. Vocabulary speech distance showed differences $(4 \%-7 \%)$ are the inter-observation points: 1:9, 8:9, 9:11, 10:11, 10:12.

c. Vocabulary distance that shows the subdialect difference $(8 \%-11 \%)$ contained in the inter-observation points: $3: 19,16: 19,18: 19,19: 20,19: 21$.

d. Vocabulary distance show dialect differences $(12 \%-16 \%)$ was not obtained at all observation points. 
e. Vocabulary distance which indicate differences in language $(17 \%-100 \%)$ was not obtained at all observation points.

\section{Map 2. Phonological Dialectometri}

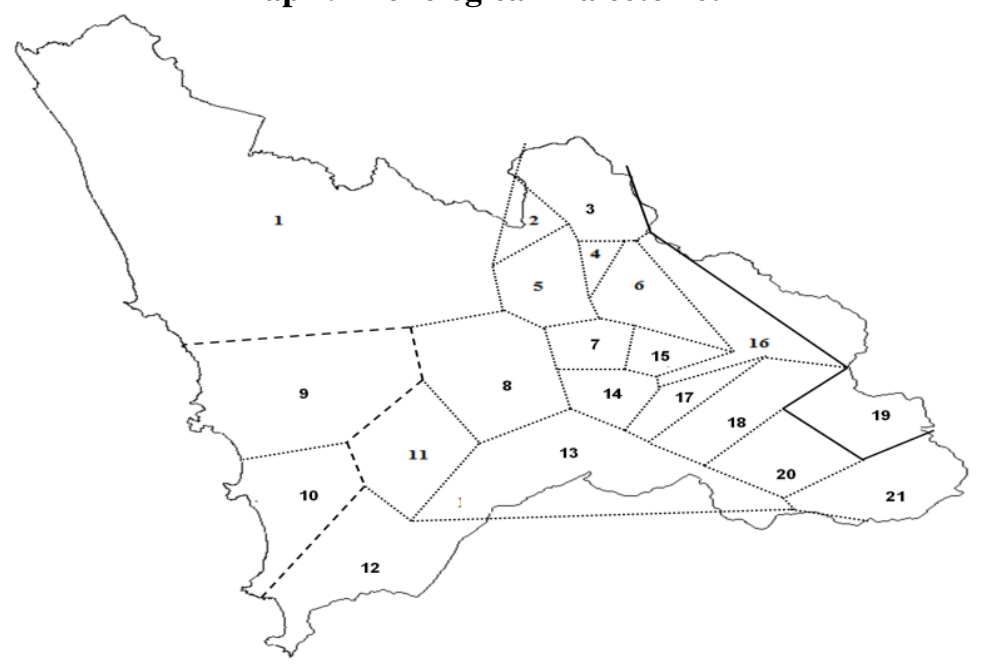

Languages different

Dialects different

Subdialects different

$\overline{--1-1-1-.-1}$ Speech different

Not different

Based on the results of dialectometri map of phonological calculation (of which there are 105 maps) above were not apparent differences in dialect and language differences in Mandailing language. There are five subdialects contained in the region between obseration points: 3:19, 16:19, 18:19, 19:20, 19:21 which covers the eastern part of the Mandailing Natal, Bukit Malintang, East Panyabungan, Kotanopan, and Muara Sipongi. Meanwhile, the area that shows the differences in speech $(4 \%-7 \%)$ contained in the inter-observation points: 1:9, 8:9, 9:11, 10:11, 10:12.

Map 3 Mandailing Dialect Grouping and Subdialect Results
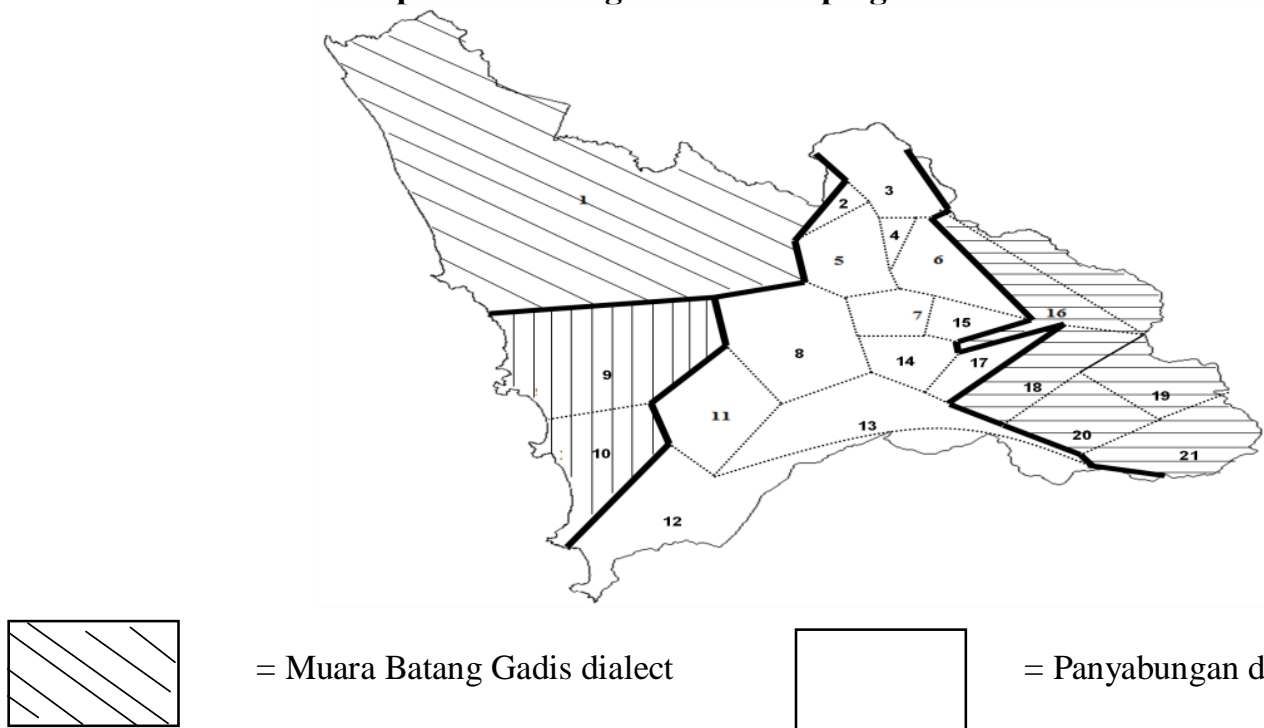

$=$ Muara Batang Gadis dialect

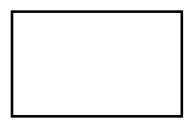

$=$ Panyabungan dialect

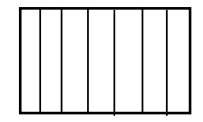

$=$ Natal dialect

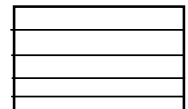

= Muara Sipongi dialect 
The maps above illustrates that in Mandailing Natal consists of four groups of dialects, namely (a) Muara Batang Gadis dialect (1), (b) Natal dialect $(9,10)$, (c) Panyabungan dialect $(2-8,11-15,17)$, and (d) Muara Sipongi dialect $(16,18-21)$.

\subsection{Use-area}

The referred of use area is an area that generally uses the vocabulary of a particular language for everyday. Use area at Mandailing Natal consist of Mandailing language use area, Malay and Minang language use areas.

\subsubsection{Mandailing Language Vocabulary use area}

Mandailing language vocabulary use area is a large area than Malay and Minang language. Mandailing language vocabulary use area spreads in the Northwest, North, Northeast and South of Mandailing Natal. Generally, Mandailing vocabulary used around Muara Batang Gadis, Siabu, Bukit Malintang, Huta Bargot, Panyabungan, South Panyabungan, Batang Natal, Lingga Bayu, Batahan, Ranto Baek, Puncak Sorik Marapi, Lembah Sorik Marapi, East Panyabungan, Tambangan and Kotanopan. Some villages that using Mandailing vocabulary are Rantau Panjang, Muara Batang Angkola, Huta Bangun, Sidojadi, Huta Bargot Dolok, Siantar, Kayu Laut, Sopo Tinjak, Simpang Bajole, Sinunukan IV, Bangun Saroha, Sibanggor Jae, Pangkat, Sirangkap, Tambangan Tonga and Sayur Maincat.

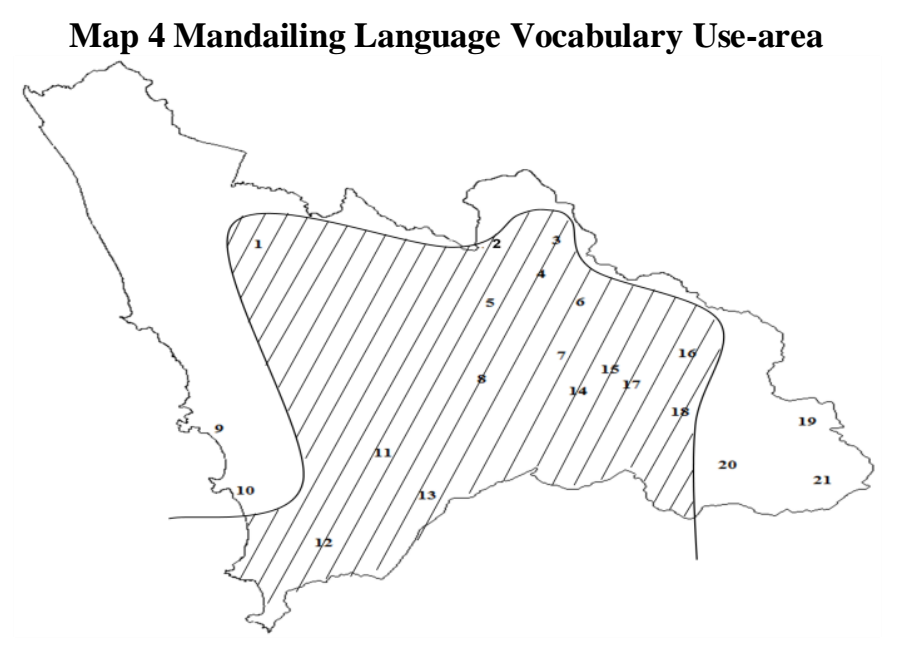

\subsubsection{Malay Language Vocabulary use area}

Based on the collection of isoglosses and vocabulary distance calculation, the use area of Malay vocabulary located in the Western region. Malay vocabulary generally used in Natal regency. The villages that use Malay vocabulary is Pasar I Natal and Pasar II Natal.

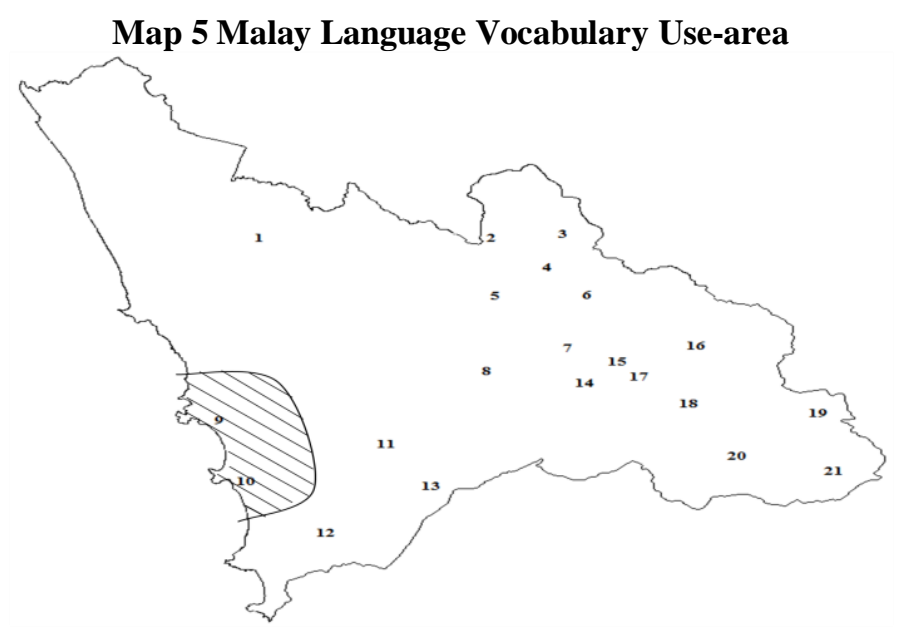

\subsubsection{Minang Language Vocabulary Use-area}


Based on the collection of isoglosses and vocabulary distance calculation, the use area of Minang vocabulary located in the Southeast at Muara Sipongi, Ulu Pungkut and Pakantan. The villages that use Minang language vocabulary is Tanjung Alai, Alahan Kae and Huta Toras.

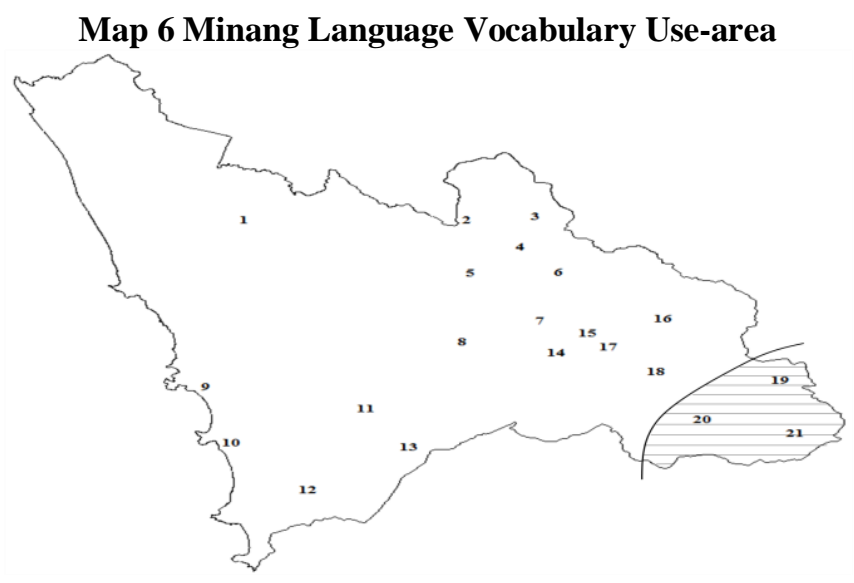

Mandailing language vocabulary use-area more dominant is Mandailing Natal regency is caused its regions bordering the South Tapanuli which contribute to social interaction. Generally, Mandailing language in Mandailing Natal and South Tapanuli have a common word or meaning, it caused Mandailing Natal is a part of the South Tapanuli and separated by the division / regional autonomy.

Malay language vocabulary use-area appeared in Mandailing Natal district at Natal regency. The location of village bordering the Indian Ocean, this region is known as the coastal areas. Malay language often use in communicating with other speakers, but the influence of the Malay language always appears and their vocabulary more different. Minang language vocabulary use-area looks in the Southeastern region Mandailing Natal. Layout of Minang language vocabulary use-area is bordered by West Sumatra province. Minang language influence in the region is significant. This is not only due to geographical factors, but because of the trade that resulted in Minang people speak Mandailing language or Mandailing people learning to speak Minang language while interacting and transacting in the market.

\section{Conclusion}

Based on the findings, we can conclude that the difference in the sound of the language, particularly in the Mandailing language, may occur regularly and irregularly (sporadic). The difference in the sounds of language that occur regularly and the sounds of language differences that occur irregularly (sporadic) each closely related to the linguistic characteristics and geographic features. To obtain maps or map language dialect, dialectology experts have been trying to develop some kind of statistics called dialectometri.

\section{References}

[1]. Ayatrohaedi, Bahasa Sunda di Daerah Cirebon (Jakarta: Balai Pustaka, 1985)

[2]. Chambers, J.K. and Peter Trudgill, Dialectology (Great Britain: Cambridge University Press, 1998)

[3]. Chomsky, Noam, The New Horizons in the Study of Language and Mind: Cakrawala Baru Kajian Bahasa dan Pikiran. Terjemahan oleh Freddy Kirana (Jakarta: Logos Wacana Ilmu, 2000)

[4]. Lauder, Multamia R.M.T, Pemetaan dan Distribusi Bahasa-Bahasa di Tangerang (Jakarta: Proyek Penelitian dan Pembinaan Bahasa dan Sastra Indonesia dan Daerah, 1993)

[5]. Nadra, Rekonstruksi Bahasa Minangkabau (Padang: Andalas University Press, 2006)

[6]. Nothofer, Bernd, Dialektatlas von Zentral-Java (Wiesbaden: Otto Harrassowitz, 1981)

[7]. Petyt, K. M, The Study of Dialect: An Introduction to Dialectology (London: Andre Deutsch Limited, 1980)

[8]. Saussure, Ferdinand de, Cours de Linguistique Generale: Pengantar Lingustik Umum. Terjemahan oleh Rahayu S. Hidayat (Yogyakarta: Gajah Mada University Press, 1988)

[9]. Sibarani, Robert dan Ridwan Hanafiah, "Geografi Dialek Bahasa Mandailing". Penelitian. Departemen Pendidikan dan Kebudayaan. Direktorat Jenderal Kebudayaan (Bagian Proyek Pembinaan Bahasa dan Sastra Indonesia dan Daerah Sumatera Utara, 2000)

[10]. Trudgill, Peter, On Dialect, Social, and Geographical Perspectives (Oxford: Basil Blackwell, 1983)

[11]. Trudgill, Peter, Sociolinguistic Variation and Change (Scotland: Edinburgh University Press, 2001)

[12]. Zulaeha, Ida, Dialektologi: Dialek Geografi \& Dialek Sosial. (Yogyakarta: Graha Ilmu, 2010) 